\title{
Treatment of Antibiotics and Antibiotic Resistant Bacteria in Swine Wastewater with Free Chlorine
}

\author{
Zhimin Qiang, ${ }^{\dagger}, \ddagger, \S$ John J. Macauley,$\|$ Melanie R. Mormile, ${ }^{\dagger}, \|$ \\ RaO Surampalli, ${ }^{\perp}$ AND Craig D. AdAms $*, \dagger, *$ \\ Environmental Research Center for Emerging Contaminants and Departments of Civil, Architectural \\ and Environmental Engineering and Biological Sciences, University of Missouri-Rolla, Rolla, \\ Missouri 65409, State Key Laboratory of Environmental Aquatic Chemistry, Research Center for \\ Eco-Environmental Sciences, Chinese Academy of Sciences, Beijing 100085, China, and \\ U.S. Environmental Protection Agency, Region 7, Kansas City, Kansas 66101
}

\begin{abstract}
Recent recognition of the occurrence of antibiotics in the environment has highlighted concerns regarding potential threats of antibiotics to humans and wildlife. Antibiotics are commonly applied to animals to prevent diseases and promote growth, making livestock agriculture a major source of antibiotic pollution. The purpose of our study was to examine chlorination technology as a method for preventing the release of antibiotics as well as antibiotic-resistant bacteria into the environment from concentrated animal feeding operations. Wastewaters from various sites of two anaerobic lagoon systems, one aerated and the other not, on a swine facility were investigated. Each system consisted of a primary treatment lagoon and a subsequent polishing lagoon. Free chlorine (or monochloramine for comparison) was applied to oxidize antibiotics and to disinfect lagoon bacteria as well. Results indicate that aeration substantially improves lagoon functionality, thereby adding both organic and ammonia removal. Ammonia present in the wastewaters plays a critical role in antibiotics decomposition and bacterial inactivation due to its rapid competition for free chlorine to form monochloramine. Generally, a chlorine dose close to breakpoint is required to achieve complete removal of antibiotics, leading to high consumption of free chlorine in most of the wastewaters examined. However, because of a low ammonia concentration in the polishing lagoon wastewater of the aerated system, a chlorine dose of $100 \mathrm{mg} / \mathrm{L}$ can effectively achieve complete removal of both antibiotics and bacteria. On the basis of our experimental findings, a possible strategy for the treatment of swine wastewater is suggested.
\end{abstract}

KEYWORDS: Antibiotic; bacteria; treatment; swine wastewater; free chlorine; monochloramine

\section{INTRODUCTION}

Antibiotics are widely used at therapeutic levels at concentrated animal feeding operations (CAFO) worldwide to treat animal diseases $(1,2)$. Additionally, antibiotics are administered in the United States at subtherapeutic levels in water or food to promote weight gain $(1,2)$, although this practice has recently been banned in the European Union due to concerns regarding promotion and proliferation of antibiotic resistant bacteria (3). An estimated yearly production of antibiotics is more than 22700 tons in the United States, of which about 50\% serve veterinary

* To whom correspondence should be addressed. Tel: +1-573-341-4041. Fax: +1-573-341-7217. E-mail: adams@umr.edu.

$\dagger$ Environmental Research Center for Emerging Contaminants, University of Missouri-Rolla.

$\doteqdot$ Department of Civil, Architectural and Environmental Engineering, University of Missouri-Rolla.

$\S$ Research Center for Eco-Environmental Sciences, Chinese Academy of Sciences.

"Department of Biological Sciences, University of Missouri-Rolla.

${ }^{\perp}$ U.S. Environmental Protection Agency. purposes (4-6). Moreover, about $90 \%$ of the veterinary antibiotics are administrated subtherapeutically to promote animal weight production (7). However, these antibiotics are commonly excreted in urine, feces, and manure as parent compounds, conjugates, or oxidation and hydrolysis byproducts (8). It is estimated that as much as $75 \%$ of the administered antibiotics can pass through, and be excreted from, the animal bodies (9).

Anaerobic lagoons are commonly used in animal agriculture at a low cost to settle manure solids and decompose various organic compounds, including carbohydrates, protein, and fats $(10,11)$. To maintain functionality, these lagoons depend on both microbial activity and management practices, such as solids separation in preceding pit systems, periodic solids removal for field application, and appropriate organic loadings (12). When animal wastes are discharged, antibiotics are simultaneously released into anaerobic lagoons. Antibiotics may accumulate in the lagoon slurry because many antibiotics do not biodegrade $(13,14)$. In fact, Meyer et al. (15) reported that relatively high 
Table 1. Physical-Chemical Properties of Selected Sulfonamides

\begin{tabular}{|c|c|c|c|c|}
\hline Compound/Code & CAS \# & MF/MW & Chemical Structure & $p \mathrm{~K}^{\mathrm{a}}$ \\
\hline $\begin{array}{c}\text { Sulfamethizole } \\
\text { SML }\end{array}$ & $144-82-1$ & $\begin{array}{c}\mathrm{C}_{9} \mathrm{H}_{10} \mathrm{~N}_{4} \mathrm{O}_{2} \mathrm{~S}_{2} \\
270.3\end{array}$ & & $\begin{array}{l}1.86 \pm 0.30 \\
5.29 \pm 0.04\end{array}$ \\
\hline $\begin{array}{c}\text { Sulfathiazole } \cdot \mathrm{Na} \\
\text { STZ }\end{array}$ & $144-74-1$ & $\begin{array}{c}\mathrm{C}_{9} \mathrm{H}_{8} \mathrm{~N}_{3} \mathrm{O}_{2} \mathrm{~S}_{2} \mathrm{Na} \\
277.3\end{array}$ & & $\begin{array}{l}2.01 \pm 0.30 \\
7.11 \pm 0.09\end{array}$ \\
\hline $\begin{array}{l}\text { Sulfamethazine } \cdot \mathrm{Na} \\
\text { SMN }\end{array}$ & $1981-58-4$ & $\begin{array}{c}\mathrm{C}_{12} \mathrm{H}_{13} \mathrm{~N}_{4} \mathrm{O}_{2} \mathrm{SNa} \\
300.3\end{array}$ & & $\begin{array}{l}2.07 \pm 0.30 \\
7.49 \pm 0.13\end{array}$ \\
\hline $\begin{array}{c}\text { Sulfamethoxazole } \\
\text { SMX }\end{array}$ & $723-46-6$ & $\begin{array}{c}\mathrm{C}_{10} \mathrm{H}_{11} \mathrm{~N}_{3} \mathrm{O}_{3} \mathrm{~S} \\
253.3\end{array}$ & & $\begin{array}{l}1.85 \pm 0.30 \\
5.60 \pm 0.04\end{array}$ \\
\hline $\begin{array}{l}\text { Sulfadimethoxine } \cdot \mathrm{Na} \\
\text { SDM }\end{array}$ & $1037-50-9$ & $\begin{array}{c}\mathrm{C}_{12} \mathrm{H}_{13} \mathrm{~N}_{4} \mathrm{O}_{4} \mathrm{SNa} \\
332.3\end{array}$ & & $\begin{array}{l}2.13 \pm 0.30 \\
6.08 \pm 0.09\end{array}$ \\
\hline
\end{tabular}

a Reference 39.

concentrations of a number of commonly used antibiotics were detected in CAFO lagoons, including tetracyclines $(1 \mathrm{mg} / \mathrm{L})$, lincosamides $(1.2 \mathrm{mg} / \mathrm{L})$, and sulfonamides $(6 \mathrm{mg} / \mathrm{L})$. Therefore, the anaerobic lagoons can act as reservoirs of various antibiotics, and subsequently, lagoon bacterial populations may develop strong resistance to these antibiotics. In a recent national reconnaissance conducted by the U.S. Geological Survey, a variety of human and veterinary antibiotics were detected in sampled U.S. streams (16). Many sulfonamides were detected in landfill leachate and down gradient groundwater, indicating a high mobility of these antibiotics (17). In particular, antibiotics were more commonly found in surface and groundwater near CAFOs and near the sites where CAFO manure was field applied as fertilizer $(5,18-20)$. Seepage, runoff, and field application of the lagoon slurry may lead to contamination of surrounding surface and groundwater with antibiotics and antibiotic resistant bacteria (21).

The occurrence of antibiotics in our environment presents two potential risks. First, antibiotics select for resistant bacteria in livestock bodies as well as in anaerobic lagoons used for animal waste storage. Second, the presence of antibiotics in streams, lakes, and water supplies encourages the growth of resistant bacteria in humans and wildlife (22). Many veterinary antibiotics have a structure and mode of action similar to those of human antibiotics (23). Consequently, the same antibiotic resistance genes and gene transfer mechanisms can be found in the microfloras of both animals and humans (6). Evidence is mounting that antibiotic resistant enteric bacteria can transfer from animals to man via the food chain or by direct contact, resulting in the establishment of a community reservoir of resistant genes (24). Microbial resistance to antibiotics is on the rise. For example, Goni-Urriza et al. (25) investigated the impact of an urban effluent on antibiotic resistance of freshwater bacterial populations. The researchers reported that $72 \%$ of Aeromonas strains and $20 \%$ of Enterobacteriaceae strains were resistant to nalidixic acid. In addition, Enterobacteriaceae exhibited resistance to tetracycline (24\%) and $\beta$-lactams (21\%), and Aeromonas exhibited resistance to tetracycline $(28 \%)$ and cotrimoxazole $(27 \%)$. The potential contamination of groundwater with bacteria and antibiotic resistant genes was found as far as $100 \mathrm{~m}$ downstream of swine lagoons $(21,26)$.
The potential threat of antibiotics to humans and wildlife brings about an urgent need to control the spread of antibiotics and antibiotic resistant bacteria from CAFO lagoons to other environments. So far, only a few studies have investigated the decomposition of antibiotics in surface, drinking, and distilled waters caused by sunlight, chlorine, and ozone (27-31). No research has been conducted on the removal of antibiotics from anaerobic lagoons at the sites of confined animal feeding operations. Chlorine is a primary disinfectant used in water and wastewater treatment facilities in the United States. It was reported that free chlorine (FC) was effective in eliminating (transforming) antibiotics (such as sulfonamides, carbadox, and trimethoprim) from distilled and surface waters $(28,32)$. Chlorine can transform antibiotics due to its strong oxidation potential as well as inactivate lagoon bacteria due to its strong disinfection potential.

The objective of this study was to investigate the potential of FC for decomposing antibiotics and simultaneously inactivating bacteria in lagoon wastewaters of a swine production facility. Sulfonamides were selected as model antibiotics in this study because of their high concentration (i.e., $6 \mathrm{mg} / \mathrm{L}$ ) detected in anaerobic lagoons relative to other antibiotics such as tetracyclines, lincosamides, macrolides, and trimethoprim (15). The effects of lagoon wastewater properties on chlorine treatment efficacy were also assessed. In addition, the potential reactivity of monochloramine (MCA) toward antibiotics and lagoon bacteria was evaluated for comparison purposes. A significant amount of dissolved ammonia was present in lagoon wastewaters that could rapidly generate MCA upon addition of FC.

\section{MATERIALS AND METHODS}

Reagents. Five study sulfonamides, including sulfamethizole (SML, $>99 \%$ ), sulfathiazole (STZ, >99\%), sulfamethazine (SMN, >99\%), sulfamethoxazole (SMX, >99\%), and sulfadimethoxine (SDM, 98\%) were purchased from Sigma (St. Louis, MO). The important physicalchemical properties of these sulfonamides are described in Table 1, including molecular formula, molecular weight, chemical structure, and acid dissociation constants $\left(\mathrm{p} K_{\mathrm{a}}\right)$. An antibiotic stock solution was prepared as a mix of the five sulfonamides with a concentration of $100 \mathrm{mg} / \mathrm{L}$ for each compound. When stored in amber bottles and in darkness to minimize potential decomposition by light, the antibiotic stock solution was found to be stable for over 2 months. 


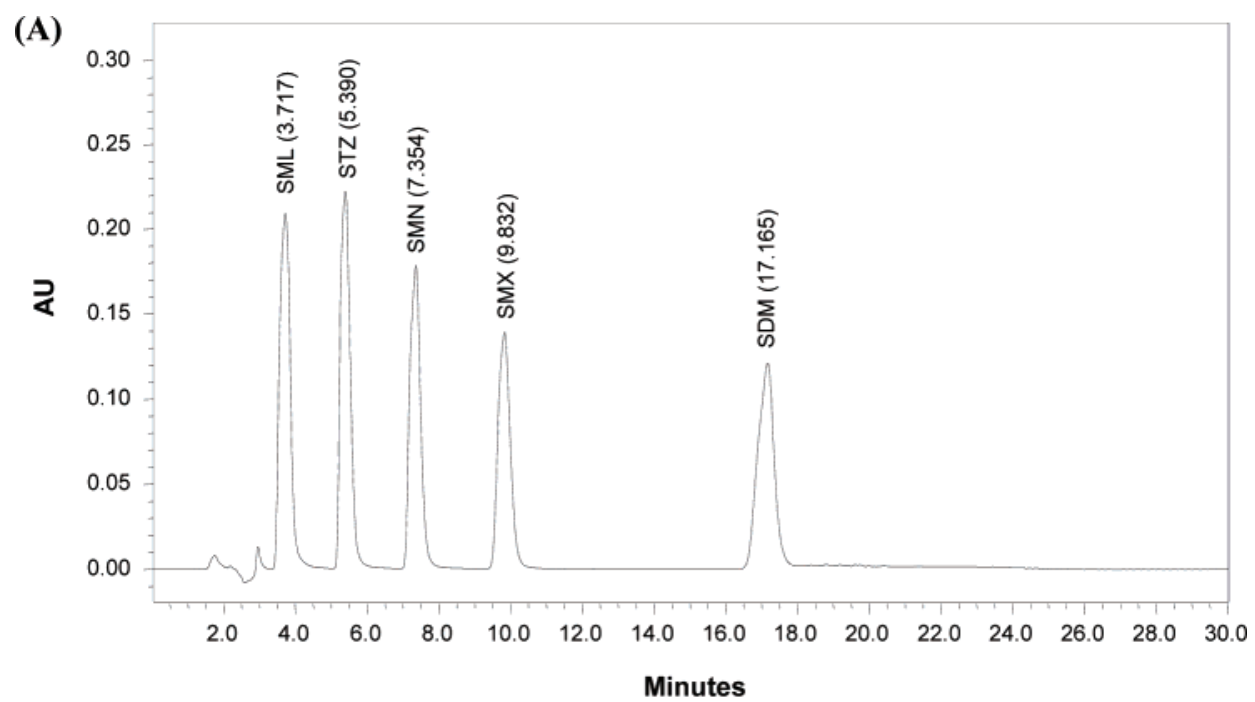

(B)

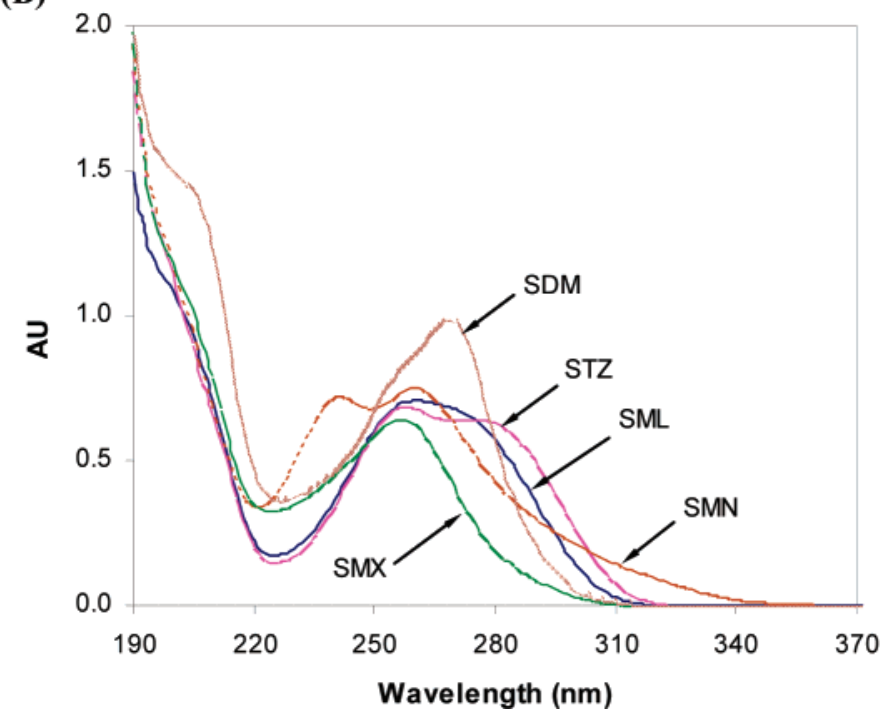

Figure 1. Detection of sulfonamides with an HPLC system: (A) HPLC chromatogram of sulfonamides (detection wavelength $=254 \mathrm{~nm}, \mathrm{C}=5 \mathrm{mg} / \mathrm{L}$ for each sulfonamide; retention times are given in minutes in parentheses) and $(B)$ characteristic ultraviolet spectra of sulfonamides $(C=0.04 \mathrm{mM}$ for each sulfonamide). Experimental conditions: $\mathrm{MQ}$ matrix, $\mathrm{KH}_{2} \mathrm{PO}_{4}=10 \mathrm{mM}, \mathrm{NaClO}_{4}=50 \mathrm{mM}$, and pH 7.6.

Certified ACS-grade ammonium chloride, sodium hydroxide, sodium perchlorate, potassium phosphate monobasic, and trace metal grade perchloric acid $(67-71 \%)$ were purchased from Fisher Scientific (Fair Lawn, NJ). Sodium hypochlorite ( $>4 \%$ by weight), purchased from Aldrich (Milwaukee, WI), was used as the source of FC. MCA was freshly prepared at a concentration of about $10000 \mathrm{mg} / \mathrm{L}$ by mixing an equal volume of $0.40 \mathrm{M} \mathrm{NaOCl}$ and $0.44 \mathrm{M} \mathrm{NH}_{4} \mathrm{Cl}$ around $\mathrm{pH} 10.5$. Ammonium chloride was used in $10 \%$ excess to suppress the spontaneous decomposition of MCA (33). Millipore water (MQ), with a resistivity of at least $18.2 \mathrm{M} \Omega \cdot \mathrm{cm}$, was produced with a water purification system (Millipore Simplicity 185, Millipore Co., Bedford, MA). $\mathrm{NaOH}$ and $\mathrm{HClO}_{4}$ solutions were prepared for $\mathrm{pH}$ adjustment.

Analysis. Dissolved organic carbon (DOC) was analyzed by using a Total Organic Carbon Analyzer (model TOC-5000A, Shimadzu Co.). Soluble chemical oxidation demand (SCOD), free ammonia, nitrate, nitrite, and total alkalinity were determined by Hach methods 8000 (dichromate reactor digestion), 10031 (salicylate method), 10020 (chromotropic acid method), 8507 (diazotization method), and 8203 (digital titration with $\mathrm{H}_{2} \mathrm{SO}_{4}$ solution) with a DR/2010 portable spectrophotometer, respectively (Hach Co., Loveland, CO). A digital conductivity meter, coupled with a platinum probe from Fisher Scientific, was used to measure sample conductivity and the concentration of total dissolved solids (TDS) as well. The spectra of individual sulfonamides and lagoon wastewaters were scanned by using a Varian spectrophotometer (Cary 50 Conc., Varian Australia PTY Ltd.,
Australia). The concentrations of FC and MCA were determined by using Hach methods 8021 (total DPD method) and 10172 (indophenol method), respectively.

Sulfonamide concentrations were determined with a Waters highperformance liquid chromatography (HPLC) system (Milford, MA) consisting of a 717 plus autosampler, a 600 controller, and a 996 photodiode array detector at a detection wavelength of $254 \mathrm{~nm}$. Data acquisition and peak integration were performed by the Empower QuickStart software. A reverse-phase $\mathrm{C}_{18}$ column (Luna $3 \mu \mathrm{m}, 150$ $\mathrm{mm} \times 3 \mathrm{~mm}$, Phenomenex, Torrance, CA) was used for sulfonamides separation and a guard cartridge (part KJ0-4282, Phenomenex) for protection of the $\mathrm{C}_{18}$ column. Two mobile phases were used in a binary gradient with a constant total flow rate of $0.5 \mathrm{~mL} / \mathrm{min}$. Solution A was prepared by mixing $90 \%$ (by volume) ammonium acetate solution (20 $\mathrm{mM}, \mathrm{pH}$ adjusted to 5.7 by acetic acid) with $10 \%$ acetonitrile. Solution B was prepared by mixing $20 \%$ solution A and $80 \%$ acetonitrile. A binary gradient was programmed over a ramp of $30 \mathrm{~min}$ for each analysis, varying from $90 \%$ of solution A to $100 \%$ of solution B in the initial $10 \mathrm{~min}$, reverting to $90 \%$ solution A in $2 \mathrm{~min}$, and maintaining this level for $18 \mathrm{~min}$. The sample injection volume was set at $100 \mu \mathrm{L}$. The sulfonamides were eluted in the increasing sequence of SML, STZ, SMN, SMX, and SDM, as shown in Figure 1A. The retention times of the sulfonamides were somewhat affected by reaction matrices (i.e., lagoon wastewaters). Therefore, as an additional confirmation tool, the characteristic UV spectrum of each sulfonamide was used for enhanced 


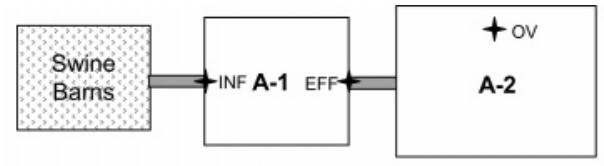

System A

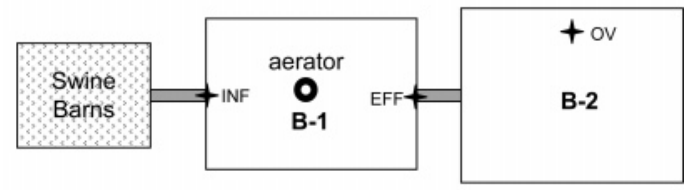

System B

+ : sampling sites

Figure 2. Illustration of sampling sites in two swine lagoon systems.

identification of specific sulfonamides, as shown in Figure 1B. Standard most probable number (MPN) analysis was employed for bacteria enumeration with brain-heart infusion (BHI) medium $(34,35)$.

Sample Collection. Samples were grabbed from two parallel lagoon systems (designated systems A and B) on an intensive swine production facility located in central Missouri from March to May of 2004. Each lagoon system consisted of two anaerobic treatment lagoons. The firststage lagoon received swine wastes periodically flushed from the swine barns, functioning as a primary treatment lagoon. The second-stage lagoon received overflow from the first-stage lagoon, functioning as a polishing lagoon. In system A, the first-stage and second-stage lagoons (designated A-1 and A-2) had water surface areas of about 0.4 and 0.7 acres, respectively. In system B, the first-stage and second-stage lagoons (designated B-1 and B-2) had water surface areas of about 0.8 and 1.0 acres, respectively. From the edge to the center of these lagoons, the water depth varied from 0.3 to $2.7 \mathrm{~m}$. Swine waste solids tended to accumulate in the first-stage lagoons (i.e., A-1 and B-1), resulting in a sludge depth of $0.3-1.2 \mathrm{~m}$. The sampling sites are illustrated in Figure 2, including the influent (INF) and effluent (EFF) of the first-stage lagoon and the bulk wastewater of the second-stage overflow (OV) lagoon. We were informed by the swine facility owner that only bacitracin was applied to treat swine diseases in the history. Our liquid chromatography/mass spectrometry analysis indicated that none of the five studied sulfonamides was detected in these lagoon matrices.

The two lagoon systems were similar except that an aerator (model Aerobisizer, Lagoon Resolutions Co., Lexington, NE) was installed in the first-stage lagoon of system B (B-1). Intermittent aeration introduced more dissolved oxygen into the lagoon and provided some mixing of lagoon contents. It was observed that aeration substantially improved bacteria activities in the B-1 lagoon. The color of the B-1 lagoon turned consistently purple, especially in warm seasons, probably due to the abundance of photosynthetic purple bacteria that could consume odor compounds such as hydrogen sulfide, ammonia, and excess volatile fatty acids (36). In contrast, prior to aerator installation, both the B-1 and the A-1 lagoons showed a consistently grayish or black color with strong emissions of an unpleasant odor.

Experimental Procedures. In antibiotic oxidation experiments, lagoon samples were first centrifuged at $21000 \mathrm{~g}$ for $10 \mathrm{~min}$ by using a programmable Thermo Forma centrifuge (Marietta, OH). The supernatant was further filtered through a $0.45 \mu \mathrm{m}$ nylon filter (Whatman Inc., Sanford, ME). The suspended solids were purposely removed by this means to exclude the interference of potential adsorption of sulfonamides onto solid surfaces, as well as to prevent the reversed-phase $\mathrm{C}_{18}$ column from clogging during antibiotic analysis. The pretreated lagoon samples were frozen in a refrigerator until use.

Antibiotic oxidation experiments were conducted in a series of 5 $\mathrm{mL}$ glass vials with lagoon wastewaters used as reaction matrices. Millipore water was also utilized as a control matrix. The effect of $\mathrm{pH}$ was investigated at $\mathrm{pH} 6.6,7.6$, and 8.6, which encompassed the $\mathrm{pH}$ conditions of the lagoon systems. Antibiotic reaction solutions were prepared separately in each matrix with each of the five studied sulfonamides set at an initial concentration of $5 \mathrm{mg} / \mathrm{L}$. After they were

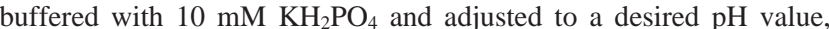
aliquots of $4 \mathrm{~mL}$ of reaction solution were dispensed to a number of 5 $\mathrm{mL}$ glass vials. A desired amount of FC or MCA was added afterward, and the vials were immediately vortexed. The reaction was allowed to proceed for $2.5 \mathrm{~h}$. Thereafter, a specific amount of ascorbic acid was added into the vials to quench the oxidant, and the antibiotic concentrations were determined using the Waters HPLC system. The concentrations of total chlorine, MCA, and free ammonia were analyzed without addition of ascorbic acid in parallel samples under identical experimental conditions. All oxidation experiments were performed in duplicate at an ambient temperature (i.e., $23 \pm 1{ }^{\circ} \mathrm{C}$ ).

Ascorbic acid was selected as a quenching agent because of its weak reduction potential as compared to commonly used sulfite and thiosulfate agents. It was reported that amine-containing pharmaceuticals were oxidized by hypochlorous acid to form chlorinated amines that could be converted back into parent compounds by reaction with thiosulfate (37).

In bacterial disinfection experiments, lagoon samples were centrifuged at $1000 \mathrm{~g}$ for $5 \mathrm{~min}$ at $4{ }^{\circ} \mathrm{C}$ in an attempt to remove large suspended solids while retaining most of the bacteria in the supernatant. The pretreated samples were buffered with $10 \mathrm{mM} \mathrm{KH}_{2} \mathrm{PO}_{4}$ and adjusted to $\mathrm{pH}$ 7.6. This $\mathrm{pH}$ closely represented the natural $\mathrm{pH}$ conditions of the lagoon systems. Moreover, at this $\mathrm{pH}$, the speciation of FC yielded approximately $50 \% \mathrm{HOCl}$ and $50 \% \mathrm{OCl}^{-}$. The $\mathrm{p} K_{\mathrm{a}}$ of hypochlorous acid was reported to be 7.63 at $15{ }^{\circ} \mathrm{C} \mathrm{(38)}$. Aliquots of $5 \mathrm{~mL}$ of pretreated sample were distributed to a series of $25 \mathrm{~mL}$ sterile conical vials. After the addition of a desired amount of FC or MCA, the vials were immediately vortexed. The reaction was allowed to proceed for $2.5 \mathrm{~h}$ in short-term disinfection and 7 days in long-term disinfection. The disinfectant was added to a new sample every 15 $\mathrm{min}$. This time interval was required to complete the serial dilutions of each sample for the subsequent MPN analysis. No effort was made to quench the disinfectant prior to sample serial dilutions considering that the addition of a quenching reagent could disturb bacterial incubation.

\section{RESULTS AND DISCUSSION}

Lagoon Wastewater Characterization. The major physical-chemical properties of lagoon wastewaters, including $\mathrm{pH}$, SCOD, DOC, free ammonia, nitrate, nitrite, total alkalinity, TDS, conductivity, UV absorbance at $254 \mathrm{~nm}$, and specific ultraviolet absorbance (SUVA), were analyzed after lagoon samples were centrifuged and filtered as described above. These properties are summarized in Table 2.

In system $\mathrm{A}$, the $\mathrm{pH}$ values of three wastewaters (i.e., INF, $\mathrm{EFF}$, and $\mathrm{OV}$ ) were slightly above neutral, ranging from 7.50 to 8.28 . The $\mathrm{pH}$ tended to increase gradually along the flow path. The SCOD values were determined to be 1102,302 , and $145 \mathrm{mg} / \mathrm{L}$ for the INF, EFF, and OV, respectively. This suggests that the lagoons were quite effective in organic decomposition and a total SCOD reduction of $87 \%$ was achieved. The DOC data showed a similar trend as the SCOD, achieving a reduction of $81 \%$ from the INF to the OV. Nitrogen was analyzed in three forms such as free ammonia, nitrate, and nitrite with their concentrations all expressed in $\mathrm{mg} / \mathrm{L}$ as $\mathrm{N}$. It is noted that the INF was collected when fresh swine waste was flushed out of swine barns, thus containing a high concentration of $\mathrm{N}$ containing compounds such as urea and proteins. Anaerobic decomposition of organic nitrogen in the first-stage lagoon A-1 generated a significant amount of ammonia, resulting in detection of more ammonia in the EFF $(390 \mathrm{mg} / \mathrm{L})$ than in the INF (141 mg/L). The second-stage lagoon A-2 had a decreased ammonia concentration, $165 \mathrm{mg} / \mathrm{L}$. A low concentration of nitrate $(2.9-3.8 \mathrm{mg} / \mathrm{L})$ was detected in all three wastewaters, but nitrite was only detected in the $\mathrm{OV}$ with a concentration as low as $0.65 \mathrm{mg} / \mathrm{L}$. Ammonia reduction in the A-2 lagoon was probably attributable to the direct assimilation of $\mathrm{NH}_{3}$ by lagoon plants and/or nitrification to $\mathrm{NO}_{2}{ }^{-}$and $\mathrm{NO}_{3}{ }^{-}$in the top aerobic layer by autotrophic nitrifying bacteria, followed by the lagoon plants' assimilation of $\mathrm{NO}_{3}{ }^{-}$or denitrification of $\mathrm{NO}_{3}{ }^{-}$to $\mathrm{N}_{2}$ in the bottom anaerobic layer. As will be addressed later, the 
Table 2. Physical-Chemical Properties of Swine Lagoon Wastewaters

\begin{tabular}{|c|c|c|c|c|c|c|}
\hline properties & A-INF & $A-E F F$ & A-OV & B-INF & B-EFF & B-OV \\
\hline $\mathrm{pH}$ & 7.50 & 8.07 & 8.28 & 7.35 & 8.03 & 8.47 \\
\hline $\mathrm{SCOD}(\mathrm{mg} / \mathrm{L})$ & $1101.5 \pm 0.7$ & $302.0 \pm 2.8$ & $145.0 \pm 1.4$ & $1038.0 \pm 5.7$ & $247.5 \pm 0.7$ & $125.5 \pm 3.5$ \\
\hline $\mathrm{DOC}(\mathrm{mg} / \mathrm{L})$ & $385.0 \pm 4.2$ & $117.0 \pm 2.8$ & $73.0 \pm 5.4$ & $359.0 \pm 7.1$ & $79.9 \pm 1.3$ & $42.7 \pm 5.2$ \\
\hline $\mathrm{NH}_{3}-\mathrm{N}(\mathrm{mg} / \mathrm{L})$ & $141.0 \pm 1.4$ & $390.0 \pm 14.1$ & $165.0 \pm 7.1$ & $120.0 \pm 2.8$ & $200.0 \pm 2.8$ & $14.0 \pm 0.7$ \\
\hline $\mathrm{NO}_{3}{ }^{-}-\mathrm{N}(\mathrm{mg} / \mathrm{L})$ & $2.9 \pm 0.8$ & $3.8 \pm 0.1$ & $3.7 \pm 1.7$ & $3.2 \pm 0.6$ & $3.9 \pm 0.7$ & $3.0 \pm 0.6$ \\
\hline $\mathrm{NO}_{2}{ }^{-}-\mathrm{N}(\mathrm{mg} / \mathrm{L})$ & $\mathrm{ND}^{a}$ & ND & $0.65 \pm 0.01$ & ND & ND & $0.10 \pm 0.01$ \\
\hline total alkalinity (mg/L) & $512.5 \pm 3.5$ & $1405.0 \pm 21.2$ & $620.0 \pm 14.1$ & $538.5 \pm 9.2$ & $722.5 \pm 3.5$ & $235.0 \pm 7.1$ \\
\hline TDS (mg/L) & 1370 & 2510 & 1360 & 1430 & 1570 & 680 \\
\hline conductivity $(\mu \mathrm{S} / \mathrm{cm})$ & 2060 & 3760 & 2035 & 2140 & 2350 & 1030 \\
\hline $\mathrm{UV}_{254 \mathrm{~nm}}$ & 1.753 & 2.179 & 1.145 & 1.687 & 1.452 & 0.653 \\
\hline SUVA (L/mg m) & 0.455 & 1.862 & 1.568 & 0.470 & 1.817 & 1.529 \\
\hline
\end{tabular}

${ }^{a} \mathrm{ND}$, not detected.

concentration of ammonia played a critical role in the oxidation of antibiotics and disinfection of bacteria with FC. In the presence of dissolved ammonia, FC would be quickly converted to MCA.

In system A, the EFF exhibited the highest total alkalinity (1045 mg/L), TDS $(2510 \mathrm{mg} / \mathrm{L})$, and conductivity $(3760 \mu \mathrm{S} /$ $\mathrm{cm})$. The anaerobic digestion of fresh swine waste in A-1 lagoon could produce more soluble solids, resulting in an increased TDS concentration and conductivity in the EFF. The ultraviolet absorbance was measured at $254 \mathrm{~nm}$, and SUVA was calculated from the values of $\mathrm{UV}_{254}$ and DOC. Because the maximum SUVA was found to be $1.862 \mathrm{~L} \mathrm{mg}^{-1} \mathrm{~m}^{-1}$ for the EFF, the lagoon wastewaters seemed to contain only a low fraction of humic acid.

In system $\mathrm{B}$, the INF showed similar properties to that of system A. However, more reduction of SCOD, DOC, $\mathrm{NH}_{3}$, total alkalinity, TDS, conductivity, and $\mathrm{UV}_{254 \mathrm{~nm}}$ was found in both EFF and OV of system B. In particular, a much lower concentration of ammonia $(14 \mathrm{mg} / \mathrm{L})$ was detected in the $\mathrm{OV}$, which could significantly reduce the effective dosage of FC. Green algae were observed to actively grow in the B-2 lagoon during the sampling period (i.e., March to May), which may assimilate more ammonia and nitrate. The nitrification process may also be enhanced because green algae could produce extra dissolved oxygen. In contrast, no algae were observed in A-2 lagoon.

On the basis of the measured properties of the wastewaters, system B appeared to function better than system A. The improved functionality of system B was probably ascribed to the intermittent aeration of B-1 lagoon. Aeration appeared to encourage the growth of purple bacteria in this lagoon and significantly improved the quality of the EFF. The large water surface areas of the B-1 and B-2 lagoons reduced their organic loadings, which may also contribute to the enhanced performance of system B.

Reaction Kinetics. The oxidation of sulfonamides with FC was investigated with batch experiments. Reaction kinetics was first examined to determine an appropriate time for accomplishing reaction completion. The oxidation experiments were conducted in MQ water, A-INF, and A-EFF over a time period of $5 \mathrm{~h}$. Three representative chlorine doses of 10, 500, and 500 $\mathrm{mg} / \mathrm{L}$ were applied to MQ, A-INF, and AEF matrices, respectively. Results indicate that the reaction kinetics can be qualitatively characterized by a rapid initial decomposition of antibiotics upon addition of $\mathrm{FC}$ and a subsequent much slower decomposition rate (Figure 3A). In MQ, FC reacts with antibiotics and the reaction curve levels off quickly after an initial decomposition of antibiotics. However, in A-INF and A-EFF, FC can react with antibiotics, ammonia, natural organic materials, and microorganisms. In particular, high concentrations of ammonia in A-INF and A-EFF react with FC to generate MCA. MCA may continue to oxidize antibiotics, although at a much slower rate. The lagoon sample A-EFF contained more ammonia than A-INF did, leading to more MCA generation and, subsequently, more antibiotics decomposition after the initial reaction. In contrast, in A-INF, more antibiotics were decomposed during the initial reaction because less FC was consumed by ammonia.

The decay of total chlorine follows a pattern similar to that of the decomposition of antibiotics, as shown in Figure 3B. In $\mathrm{MQ}$, the presence of total chlorine residue implies that some chlorinated organic byproducts are still reactive toward DPD. The total chlorine residue should not contain any FC; otherwise, more antibiotics would be decomposed. Sulfonamides contain an amino group $\left(-\mathrm{NH}_{2}\right)$ whose two hydrogen atoms can be readily substituted by chlorine (32). Therefore, it seems likely that the chlorinated amine group possesses reactivity toward DPD. In A-INF and A-EFF, the total chlorine residue can consist of MCA and some actively chlorinated organic byproducts.

On the basis of the qualitative kinetic data, a reaction time of $2.5 \mathrm{~h}$ was selected for subsequent dose-and-response experiments. The reaction could approximately reach completion within this time period.

Oxidation of Antibiotics with FC. Oxidation of antibiotics was first conducted in MQ and the INF, EFF, and OV of system A. Results indicate that all sulfonamides are decomposed at 25 $\mathrm{mg} / \mathrm{L} \mathrm{FC}$ dose $(353 \mu \mathrm{M})$ at $\mathrm{pH} 6.6$ in MQ (Figure 4). The initial concentration of each sulfonamide was $5 \mathrm{mg} / \mathrm{L}$, resulting in a molar concentration of $18.5 \mu \mathrm{M}$ SML, $18.0 \mu \mathrm{M} \mathrm{STZ,} 16.7 \mu \mathrm{M}$ SMN, $19.7 \mu \mathrm{M}$ SMX, and $15.0 \mu \mathrm{M}$ SDM. The total molar concentration of all sulfonamides is $88.0 \mu \mathrm{M}$. The molar ratio of FC to sulfonamides for complete antibiotics removal is thus calculated to be 4.01:1 on average. Besides substituting the two amino hydrogen atoms, chlorine may also attack the benzene ring of a sulfonamide as well as reaction byproducts such as 3-amino-5-methylisoxazole (32). In contrast, high FC doses of 700,2000 , and $1100 \mathrm{mg} / \mathrm{L}$ are required to attain complete removal of sulfonamides from A-INF, A-EFF, and A-OV at $\mathrm{pH}$ 6.6, respectively, primarily due to the presence of ammonia (Figure 4). The chlorine consumption by sulfonamides, as exhibited in MQ matrix, is insignificant in comparison with the chlorine consumption by the natural organic compounds present in A-INF, A-EFF, and A-OV. Therefore, the chlorine demands of the INF, EFF, and OV of lagoon system A were approximately 700,2000 , and $1100 \mathrm{mg} / \mathrm{L}$ at the reaction time of $2.5 \mathrm{~h}$. Among the five antibiotics examined, SDM appears to be most reactive, while SML is the least reactive toward FC.

The concentrations of total chlorine, MCA, and ammonia that 


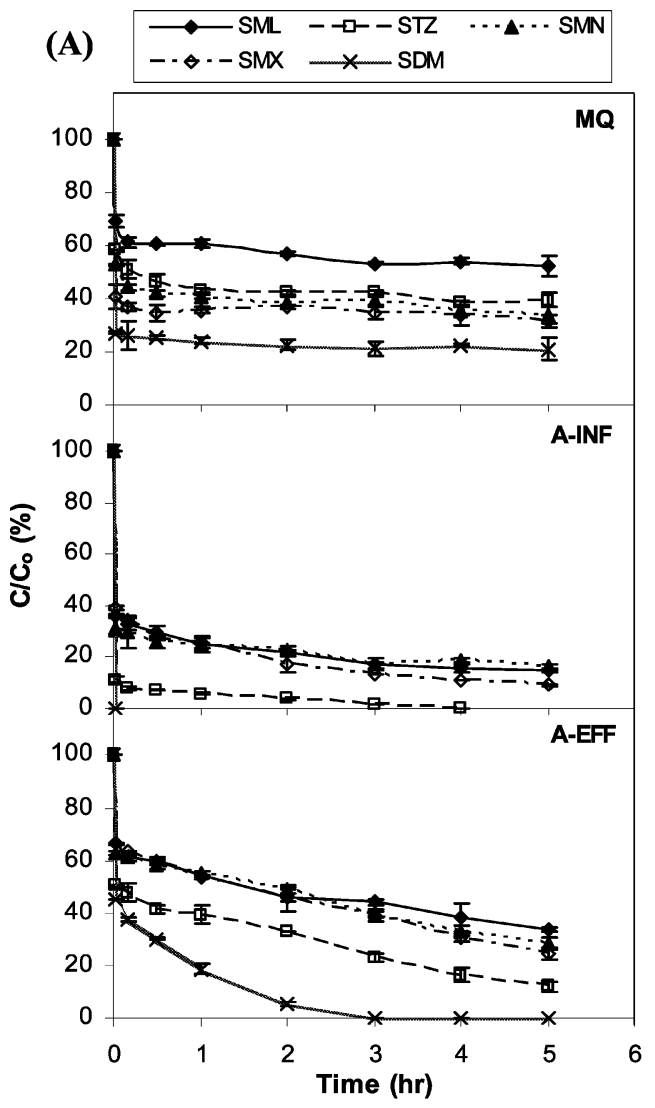

(B)

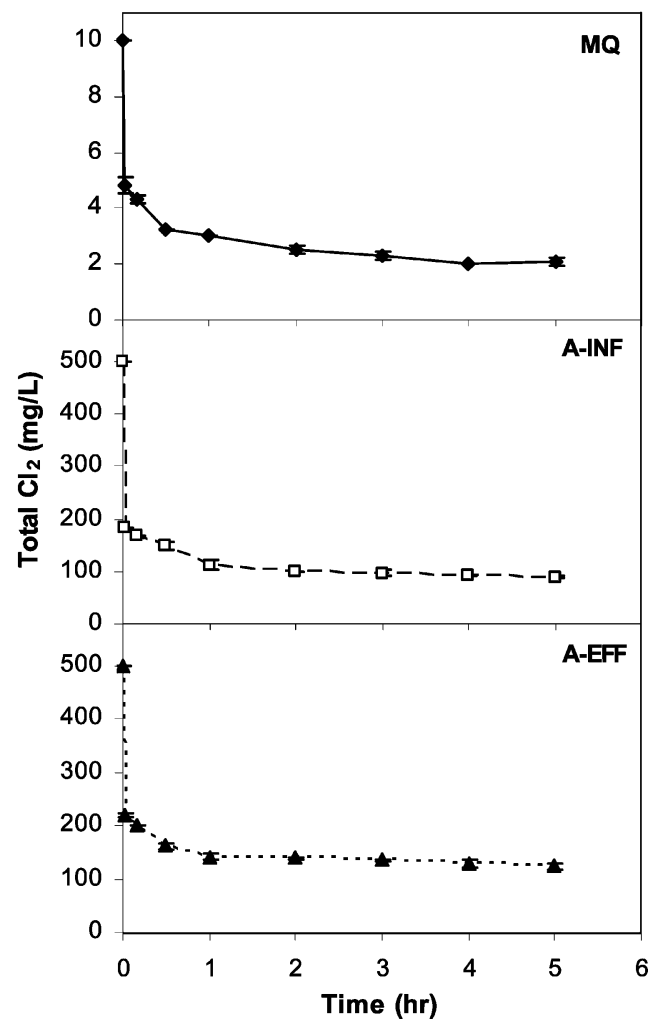

Figure 3. Oxidation of sulfonamides with FC as a function of reaction time in Millipore water and the INF and EFF of system A: (A) decomposition of sulfonamides and (B) decay of total chlorine. Data are from duplicate runs (means \pm standard deviation). Experimental conditions: $\mathrm{pH} 6.6$; for MQ, $\mathrm{FC}$ dose $=10 \mathrm{mg} / \mathrm{L}, \mathrm{KH}_{2} \mathrm{PO}_{4}=10 \mathrm{mM}$, and $\mathrm{NaClO}_{4}=50 \mathrm{mM}$; for A-INF and A-EFF, FC dose $=500 \mathrm{mg} / \mathrm{L}$.

were determined at the end of each reaction in MQ, A-INF, and A-EFF are plotted as a function of FC dose in Figure 5. In $\mathrm{MQ}$, the concentration of total chlorine residue increases linearly up to $25 \mathrm{mg} / \mathrm{L}$ FC dose and thereafter increases more quickly due to the complete removal of all sulfonamides. According to chlorination chemistry, MCA is predominately formed when the applied $\mathrm{Cl}_{2}: \mathrm{NH}_{3}-\mathrm{N}$ ratio (CNR) is less than 5:1 (by weight). As CNR increases from 5:1 to 7.6:1, a breakpoint reaction occurs, reducing the total chlorine residue level to a minimum. As CNR goes above 7.6:1, FC and trichloramine start to appear (40). The ammonia concentrations in A-INF and A-EFF were determined to be 141 and $390 \mathrm{mg} / \mathrm{L}$, respectively (Table 2). To reach 5:1 and 7.6:1 of CNR, FC doses as high as 705 and $1072 \mathrm{mg} / \mathrm{L}$ are required for A-INF and 1950 and $2964 \mathrm{mg} / \mathrm{L}$ for A-EFF, respectively. Results in Figure 5 indicate that for A-INF, the total chlorine residue curve exhibits a hump and a valley at 700 and $1100 \mathrm{mg} / \mathrm{L}$ FC doses, respectively. Ammonia gets completely destroyed at $1100 \mathrm{mg} / \mathrm{L} \mathrm{FC}$ dose (i.e., CNR $=$ 7.6:1, breakpoint), and the maximum MCA concentration appears at $700 \mathrm{mg} / \mathrm{L} \mathrm{FC}$ dose $(\mathrm{CNR}=5: 1)$. The complete removal of antibiotics can only be achieved at the CNR of 5:1 in A-INF at pH 6.6 (Figure 4). Our experiments also show that at $\mathrm{pH} 7.6$ and 8.6, a CNR of 7.6:1 is needed to decompose all sulfonamides in A-INF. Similar results are observed for A-EFF. The total chlorine residue curve shows a hump and a valley at $2000(\mathrm{CNR}=5: 1)$ and $3000 \mathrm{mg} / \mathrm{L}(\mathrm{CNR}=7.6: 1) \mathrm{FC}$ doses, respectively. Ammonia gets completely destroyed at $3000 \mathrm{mg} / \mathrm{L}$ FC dose, and the maximum MCA concentration appears at 2000 $\mathrm{mg} / \mathrm{L}$ FC dose. All antibiotics are decomposed at the CNR of 5:1 in A-EFF at pH 6.6 (Figure 4). At pH 7.6 and 8.6, a CNR of 5:1 can also decompose all sulfonamides, although at a decreased reaction rate. A-OV contains an ammonia concentra- tion of $165 \mathrm{mg} / \mathrm{L}$, similar to A-INF. Consequently, a similar antibiotics decomposition pattern is observed. Complete removal of sulfonamides is achieved at $700-1100 \mathrm{mg} / \mathrm{L}$ FC doses in $\mathrm{A}-\mathrm{OV}$ at $\mathrm{pH} 6.6$ (Figure 4). In brief, it is clearly seen that ammonia is a critical factor that controls the effective dose of FC that can completely remove antibiotics. The higher the ammonia concentration that is present in swine wastewater, the larger the FC dose that will be required for decomposition of antibiotics.

The effect of $\mathrm{pH}$ on antibiotics decomposition is exemplified by SMX in A-INF and A-EFF, as shown in Figure 6. Results indicate that the decomposition of SMX generally favors a low $\mathrm{pH}$. This also holds true for all of the other sulfonamides within the $\mathrm{pH}$ range of 6.6-8.6 in A-INF and A-EFF. Dodd and Huang (32) reported that $\mathrm{HOCl}$, rather than $\mathrm{OCl}^{-}$, represents the primary oxidant species reacting with SMX. As the $\mathrm{pH}$ decreases, the fraction of $\mathrm{HOCl}$ increases; thus, more SMX gets decomposed during the initial reaction. It should be pointed out that once FC is depleted and MCA takes over to become the primary oxidant species, $\mathrm{pH}$ will have no effect on MCA. The $\mathrm{p} K_{\mathrm{a}}$ of MCA was reported to be as low as $-1.45(41)$, so MCA speciation is negligible, except under an extremely acidic $\mathrm{pH}$ condition. Moreover, the speciation of sulfonamides under different $\mathrm{pH}$ conditions can also affect the overall reaction rate because neutral and charged sulfonamides have varied reactivities toward FC. Therefore, the overall reaction rate between $\mathrm{FC}$ and sulfonamides may not always increase as $\mathrm{pH}$ decreases.

The oxidation of antibiotics with FC was also studied in the INF, EFF, and OV of system B at pH 7.6, as shown in Figure 7. The ammonia concentrations were determined to be 120,200 , and $14 \mathrm{mg} / \mathrm{L}$ in B-INF, B-EFF, and B-OV, respectively. To oxidize all antibiotics, the respective FC doses are 700, 1100, 

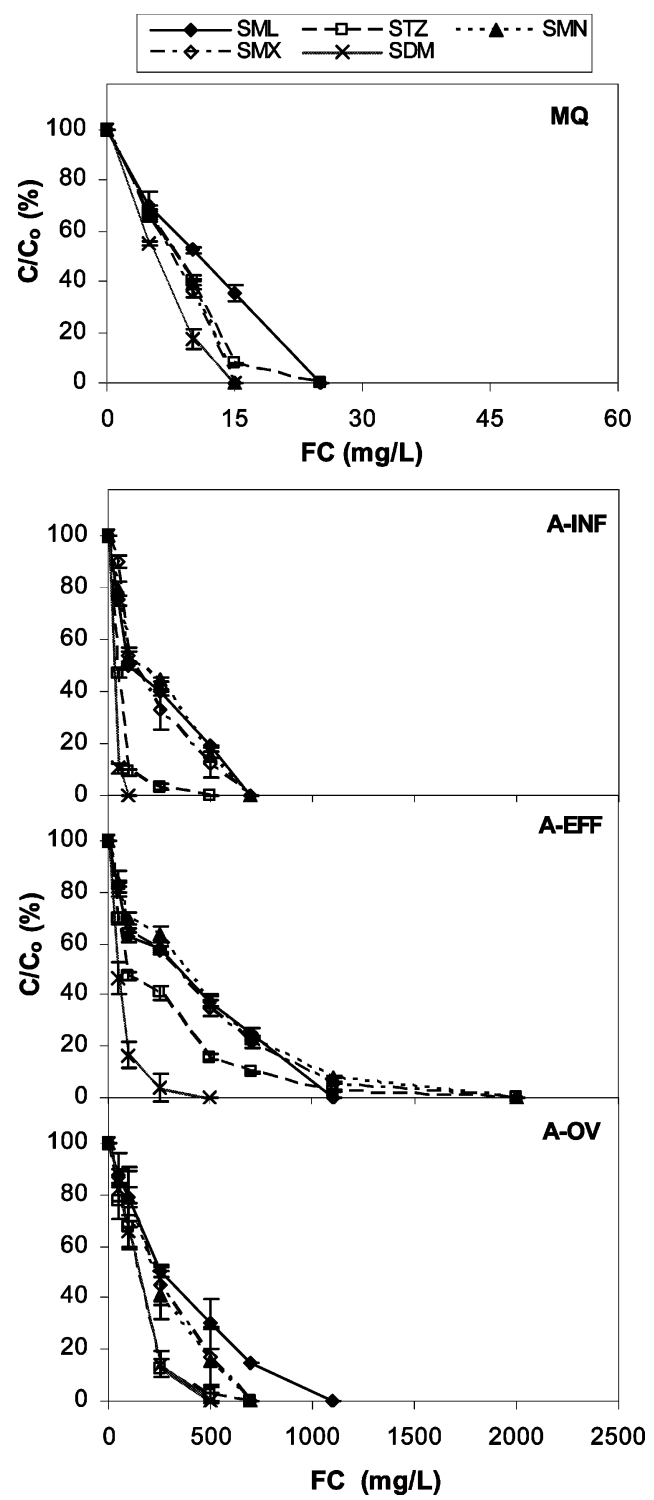

Figure 4. Decomposition of sulfonamides as a function of $\mathrm{FC}$ dose in Millipore water and the INF, EFF, and OV of system A. Data are from duplicate runs (means \pm standard deviation). Experimental conditions: reaction time $=2.5 \mathrm{~h}$ and $\mathrm{pH} 6.6$; for $\mathrm{MQ}, \mathrm{KH}_{2} \mathrm{PO}_{4}=10 \mathrm{mM}$ and $\mathrm{NaClO}_{4}$ $=50 \mathrm{mM}$.

and $100 \mathrm{mg} / \mathrm{L}$, corresponding to a CNR value between 5:1 and 7.6:1 for specific wastewaters. The CNR values agree with those found in system A. In particular, the OV contains a very low ammonia concentration; thus, a $100 \mathrm{mg} / \mathrm{L}$ FC dose can completely oxidize all of the antibiotics (Figure 7). The concentrations of total chlorine, MCA, and ammonia were monitored at the end of each reaction in B-OV. Results in Figure 7 further indicate that the maximum concentration of MCA appears at $75 \mathrm{mg} / \mathrm{L} \mathrm{FC} \mathrm{dose}(\mathrm{CNR} \approx 5: 1)$, and all ammonia gets destroyed at a $100 \mathrm{mg} / \mathrm{L} \mathrm{FC} \mathrm{dose}(\mathrm{CNR} \approx 7.6$ : 1).

Oxidation of Antibiotics with MCA. As a comparison, the application of MCA to antibiotics oxidation was investigated in MQ water and one swine wastewater (A-INF) at $\mathrm{pH}$ 6.6. The dose of $\mathrm{MCA}$ is expressed as $\mathrm{mg} / \mathrm{L} \mathrm{Cl}_{2}$. Figure 8 shows the decomposition of sulfonamides and the change in total chlorine and MCA concentrations as a function of the MCA dose. Results indicate that MCA oxidizes sulfonamides more slowly than FC. In $\mathrm{MQ}$, at an MCA dose of $25 \mathrm{mg} / \mathrm{L}\left(\right.$ as $\left.\mathrm{Cl}_{2}\right)$, only $\mathrm{SDM}$ is completely removed (Figure 8A). In contrast, a $25 \mathrm{mg} / \mathrm{L} \mathrm{FC}$
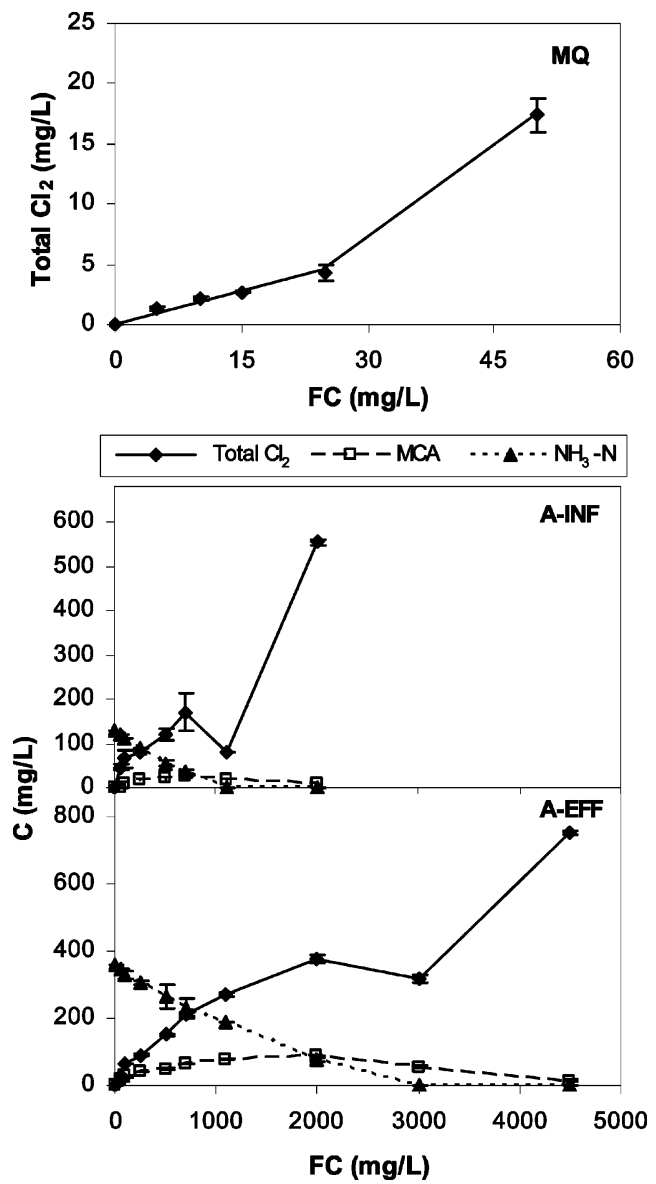

Figure 5. Change of total chlorine, MCA, and ammonia concentrations with FC doses in Millipore water and the INF and EFF of system A. The concentrations of total chlorine and MCA are expressed in $\mathrm{mg} / \mathrm{L}$ as $\mathrm{Cl}_{2}$, and the concentration of ammonia is expressed in $\mathrm{mg} / \mathrm{L}$ as $\mathrm{N}$. Data are from duplicate runs (means \pm standard deviation). Experimental conditions: reaction time $=2.5 \mathrm{~h}$; for $\mathrm{MQ}, \mathrm{KH}_{2} \mathrm{PO}_{4}=10 \mathrm{mM}$ and $\mathrm{NaClO}_{4}=$ $50 \mathrm{mM}$; for A-INF and A-EFF, pH 6.6.

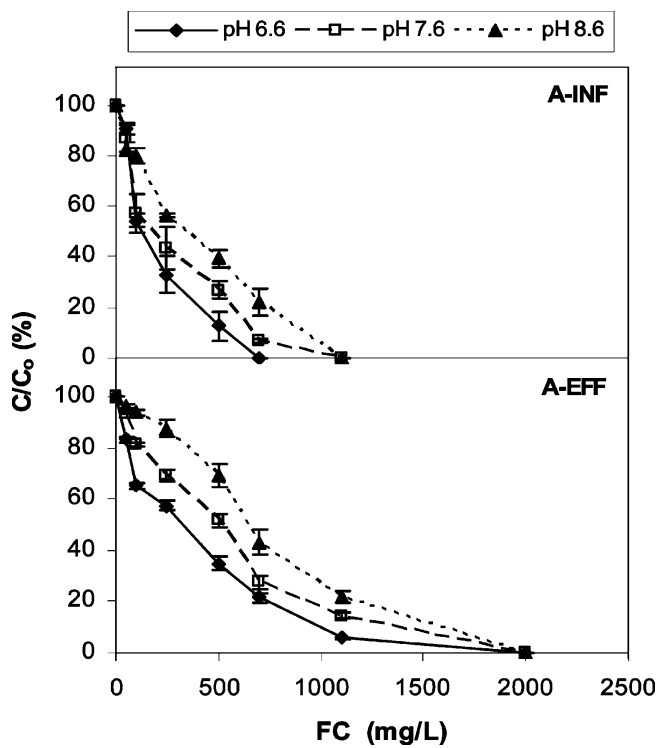

Figure 6. Effect of $\mathrm{pH}$ on SMX decompostion with $\mathrm{FC}$ in Millipore water and the INF and EFF of system A. Data are from duplicate runs (means \pm standard deviation). Experimental conditions: reaction time $=2.5 \mathrm{~h}$; for $\mathrm{MQ}, \mathrm{KH}_{2} \mathrm{PO}_{4}=10 \mathrm{mM}$ and $\mathrm{NaClO}_{4}=50 \mathrm{mM}$.

dose can decompose all sulfonamides in MQ (Figure 4). The rate of sulfonamide decomposition significantly decreases when 

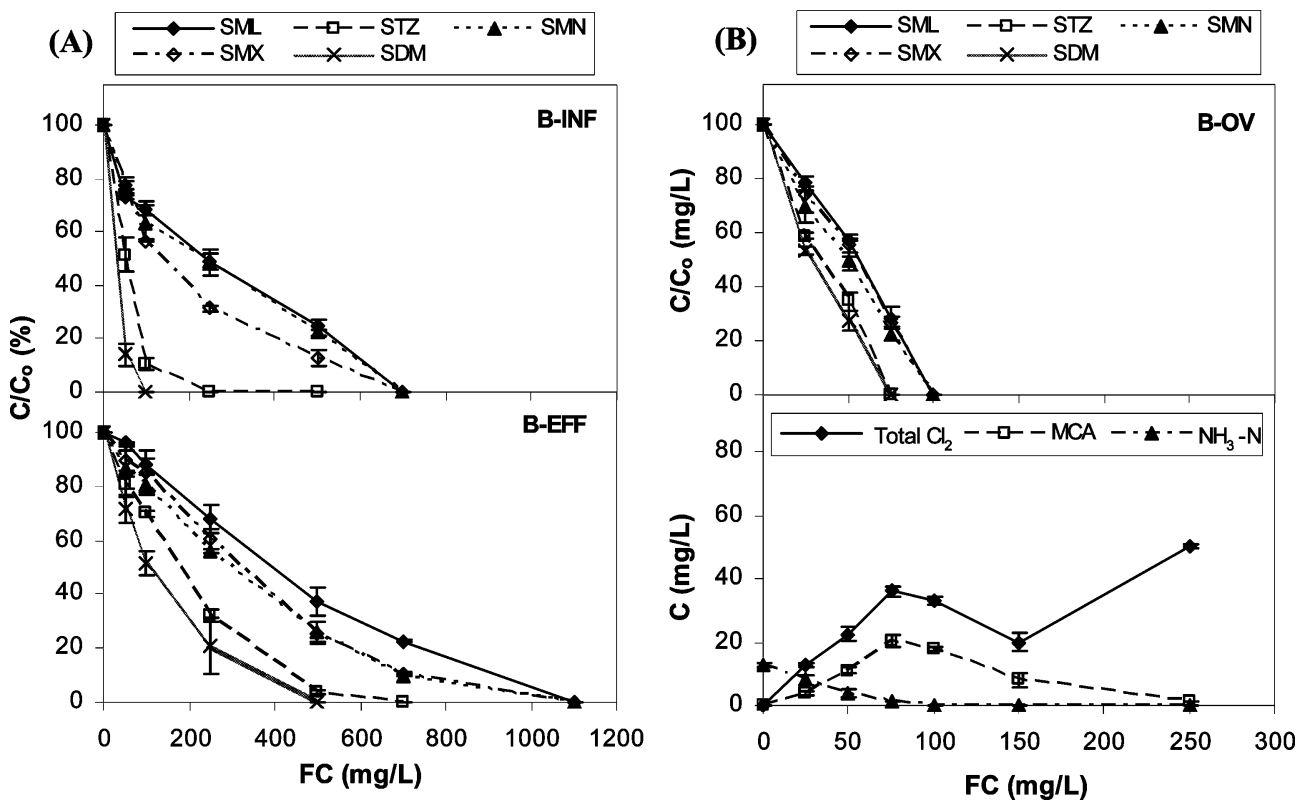

Figure 7. Oxidation of sulfonamides as a function of FC dose in the INF, EFF, and OV of system B: (A) decomposition of sulfonamides in the INF and EFF and (B) decomposition of sulfonamides and change of total chlorine, MCA, and ammonia concentrations in the overflow. The concentrations of total chlorine and MCA are expressed in $\mathrm{mg} / \mathrm{L}$ as $\mathrm{Cl}_{2}$, and the concentration of ammonia is expressed in $\mathrm{mg} / \mathrm{L}$ as $\mathrm{N}$. Data are from duplicate runs (means \pm standard deviation). Experimental conditions: reaction time $=2.5 \mathrm{~h}$ and $\mathrm{pH} 7.6$.

(A)

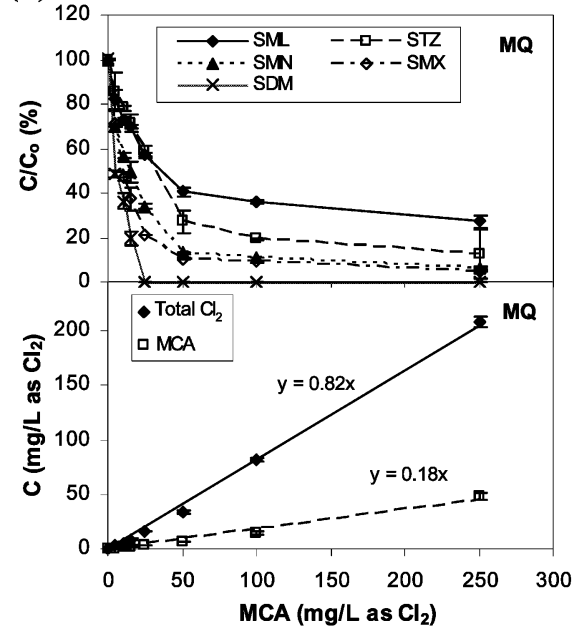

(B)

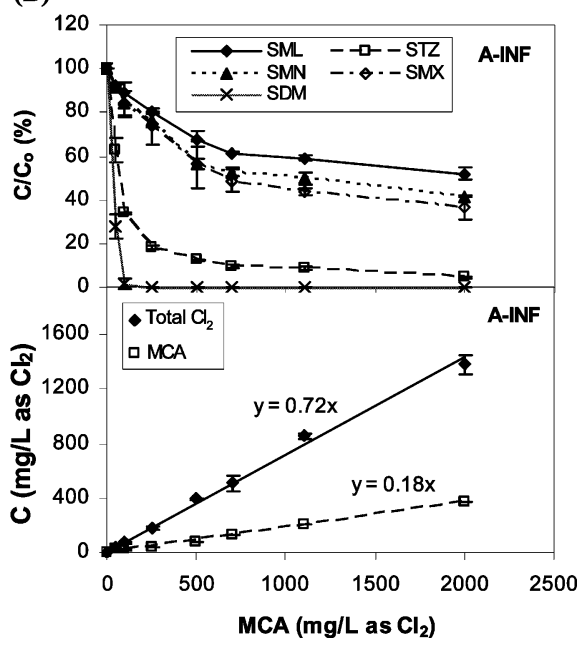

Figure 8. Oxidation of sulfonamides with MCA in (A) Millipore water and (B) the INF of system A. Data are from duplicate runs (means \pm standard deviation). Experimental conditions: reaction time $=2.5 \mathrm{~h}$ and $\mathrm{pH} 6.6$; for $\mathrm{MQ}, \mathrm{KH}_{2} \mathrm{PO}_{4}=10 \mathrm{mM}$ and $\mathrm{NaClO}_{4}=50 \mathrm{mM}$.

the MCA dose is above $50 \mathrm{mg} / \mathrm{L}$ (as $\mathrm{Cl}_{2}$ ), probably due to enhanced self-decomposition of MCA at higher concentrations to other combined chlorine forms (e.g., dichloramine and trichloramine). The residual concentrations of total chlorine and MCA respond linearly to the MCA dose (Figure 8A). The residual concentration of total chlorine increases more rapidly with the MCA dose (slope $=0.82$ ) than that of MCA (slope = 0.18). At $250 \mathrm{mg} / \mathrm{L}\left(\right.$ as $\mathrm{Cl}_{2}$ ) MCA dose, MCA residue $(47.5$ $\mathrm{mg} / \mathrm{L}$ ) only contributes to $23 \%$ of total chlorine residue (208 $\mathrm{mg} / \mathrm{L}$ ). This difference may be attributed to the formation of actively chlorinated byproducts and other combined chlorine forms. Results also indicate that SDM appears to be most reactive while SML is least reactive toward MCA. This is similar to the observed reactions between FC and sulfonamides.

MCA was also directly applied to swine wastewater, taking A-INF as an example, up to a dose of $2000 \mathrm{mg} / \mathrm{L}\left(\mathrm{as} \mathrm{Cl}_{2}\right.$ ). Results in Figure 8B indicate that in A-INF the decomposition of antibiotics is relatively effective up to a $500 \mathrm{mg} / \mathrm{L}\left(\mathrm{as} \mathrm{Cl}_{2}\right)$ MCA dose. Above this dose, a much slower rate of antibiotics decomposition follows, probably due to enhanced self-decomposition of MCA at high concentrations. SDM is the only antibiotic that gets completely removed, while part of the other sulfonamides remains in the wastewater, even at the highest MCA dose of $2000 \mathrm{mg} / \mathrm{L}\left(\right.$ as $\mathrm{Cl}_{2}$ ). As mentioned above, a 700 $\mathrm{mg} / \mathrm{L}$ FC dose can completely oxidize all of the antibiotics in A-INF at $\mathrm{pH}$ 6.6. This indicates that FC is more efficient in oxidizing antibiotics in ammonia-containing swine wastewater than MCA. Results also indicate that similar to what is observed in $\mathrm{MQ}$, the total chlorine and MCA residues increase as a linear function of a MCA dose in A-INF with a slope of 0.72 and 0.18 , respectively. Again, the difference between total chlorine and MCA may be attributed to the formation of actively chlorinated byproducts and other combined chlorine forms in swine wastewater, which still possess reactivity toward DPD. In addition, more total chlorine and MCA remain at the end of each reaction in MCA application (Figure 8B) than in FC application (Figure 4). For example, with a $2000 \mathrm{mg} / \mathrm{L}\left(\right.$ as $\left.\mathrm{Cl}_{2}\right)$ oxidant dose, the residual concentrations of total chlorine and 

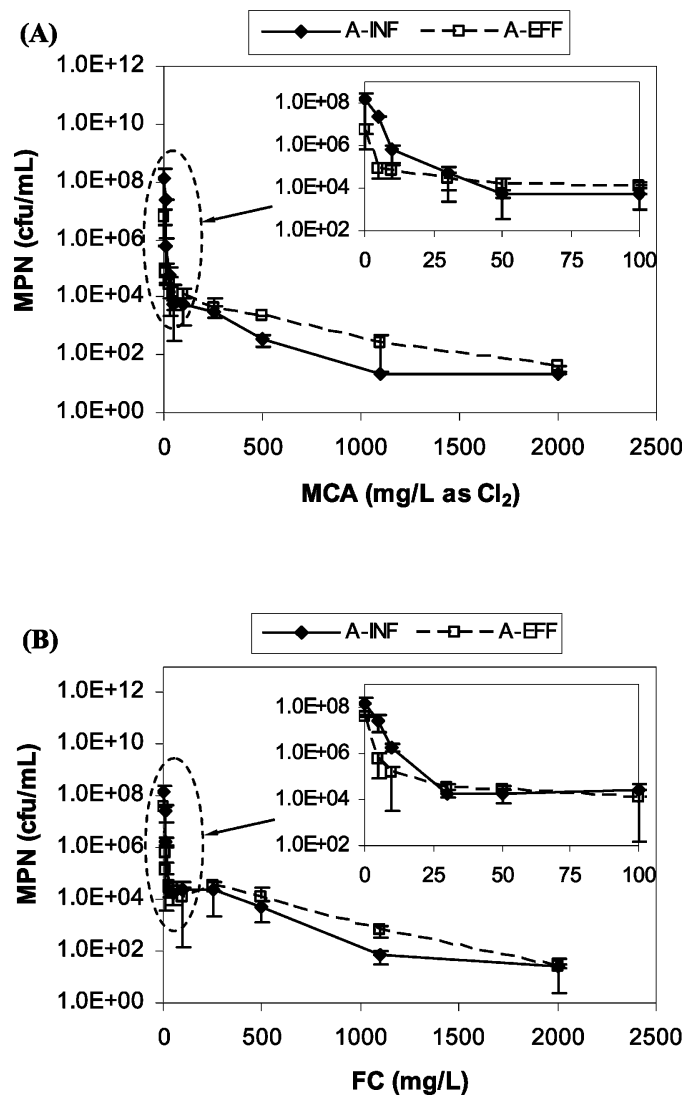

Figure 9. Inactivation of bacteria in the INF and EFF of system A with (A) MCA and (B) FC. Data are from three-tube MPN assays that were run twice (means of MPN \pm standard deviation). Experimental conditions: reaction time $=2.5 \mathrm{~h}, \mathrm{pH} \mathrm{7.6}$, and room temperature $\left(23 \pm 1^{\circ} \mathrm{C}\right)$.
MCA were determined to be 1380 and $372 \mathrm{mg} / \mathrm{L}$ in the MCA application and 555 and $9 \mathrm{mg} / \mathrm{L}$ in the $\mathrm{FC}$ application, respectively. Less consumption of the oxidants in the MCA application may reflect less decomposition of antibiotics.

Short-Term Disinfection of Bacteria. Our previous work found that a notable portion of bacteria in the A-1 lagoon exhibited significant resistance to selected antibiotics (34). When BHI, a medium, was separately amended with $32 \mathrm{mg} / \mathrm{L}$ lincomycin, chlortetracycline, and tetracycline and $256 \mathrm{mg} / \mathrm{L}$ SMN, the percentages of culturable lagoon bacteria reached 23 , 100,29 , and $4 \%$, respectively, as compared to antibiotic-free controls (34). To prevent release of antibiotic resistant bacteria from swine lagoons into surrounding environments, the disinfection potential of FC and MCA was investigated in this work. Total bacteria populations were enumerated to evaluate disinfection efficiencies instead of specific antibiotic resistant bacteria populations.

Disinfection experiments were first carried out in A-INF and A-EFF with a reaction time of $2.5 \mathrm{~h}$ using FC and MCA separately. The lagoon sample A-INF contained approximately 1 order of magnitude more bacteria than A-EFF. Results indicate that the bacteria are rapidly inactivated with a MCA dose of 50 $\mathrm{mg} / \mathrm{L}\left(\right.$ as $\mathrm{Cl}_{2}$ ); thereafter, a much smaller inactivation rate follows, up to a MCA dose of $2000 \mathrm{mg} / \mathrm{L}$ (as $\mathrm{Cl}_{2}$ ) for both matrices (Figure 9A). With a $50 \mathrm{mg} / \mathrm{L}\left(\right.$ as $\left.\mathrm{Cl}_{2}\right) \mathrm{MCA}$ dose, the bacterial inactivation efficiencies are approximately $4 \mathrm{log}$ and $3 \log$ for A-INF and A-EFF, respectively. With a $2000 \mathrm{mg} / \mathrm{L}$ (as $\mathrm{Cl}_{2}$ ) MCA dose, the inactivation efficiencies increase to approximately $7 \mathrm{log}$ and $5 \log$ for A-INF and A-EFF, respectively. FC exerts a potential on bacterial inactivation that is similar to that of MCA, as shown in Figure 9B. With 50 and $2000 \mathrm{mg} / \mathrm{L}$ FC doses, approximately $4 \log$ and 7 log inactivation

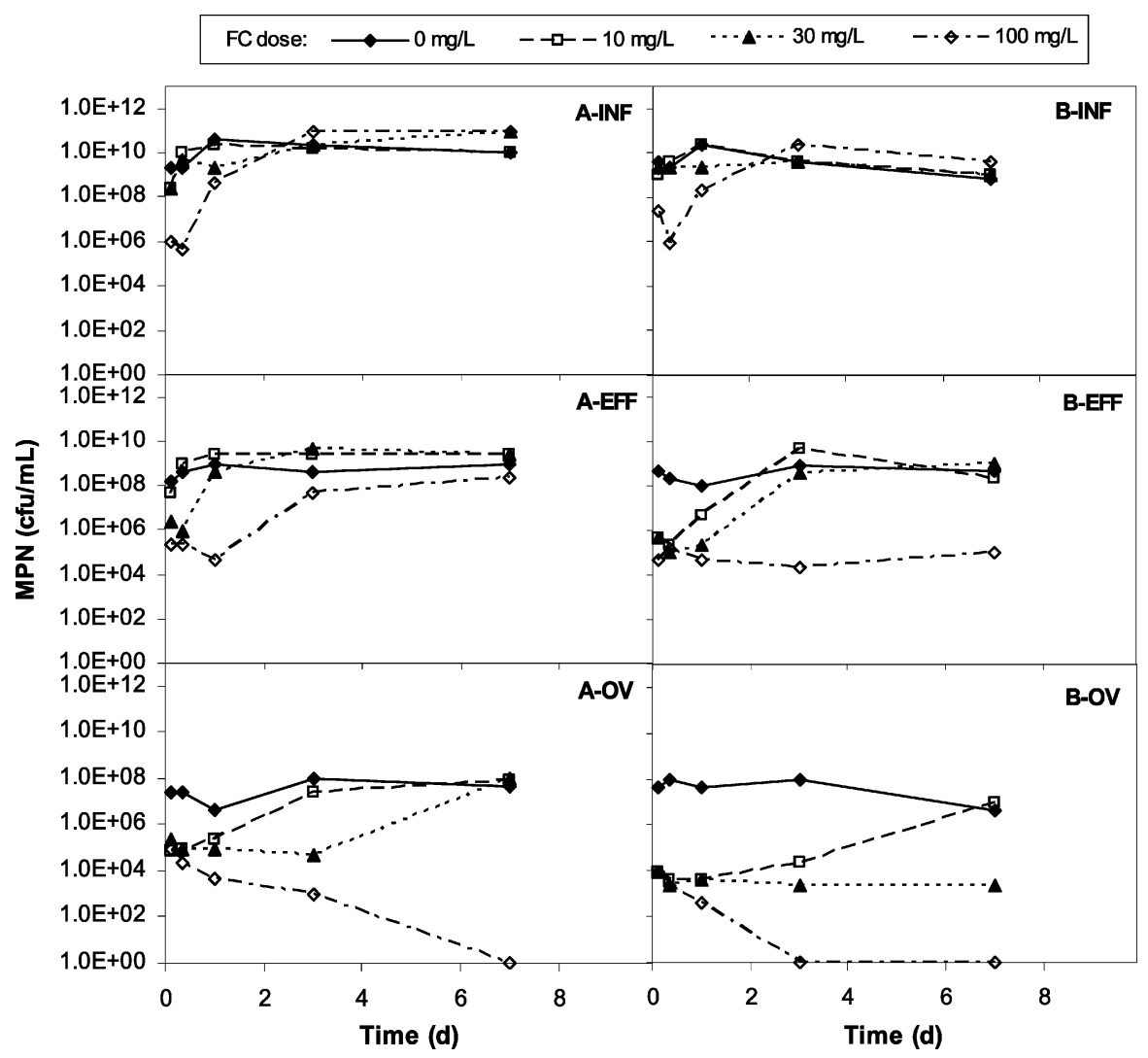

Figure 10. Long-term disinfection of bacteria with FC as a function of reaction time in systems $A$ and $B$. Data are from three-tube MPN assays that were run twice (means of MPN \pm standard deviation). Experimental conditions: $\mathrm{pH} 7.6$ and room temperature $\left(23 \pm 1^{\circ} \mathrm{C}\right)$. 
efficiencies are achieved for A-INF and $3 \log$ and $6 \log$ for A-EFF, respectively.

It is noted that about $20-40 \mathrm{cfu} / \mathrm{mL}$ bacteria could survive the highest dose (i.e., $2000 \mathrm{mg} / \mathrm{L}$ ) of either MCA or FC. The A-INF and A-EFF were simply pretreated by centrifugation at $1000 \mathrm{~g}$ for $5 \mathrm{~min}$; the small particles that remain in the wastewater may protect bacteria from being inactivated by a disinfectant, even if a high dose is administered. In addition, the natural organic materials present in the wastewaters may consume a significant fraction of the disinfectant. In our previous work, two bacterial strains in A-1 lagoon that survived a chlorine dose of $500 \mathrm{mg} / \mathrm{L}$ were isolated and identified as being closely related to Bacillus subtilis and Bacillus licheniformis (34). Although a small portion of bacteria possess resistance to MCA and $\mathrm{FC}$, a disinfectant dose of $50 \mathrm{mg} / \mathrm{L}$ still achieves a bacterial inactivation efficiency of 3-4 log in A-INF and A-EFF.

Long-Term Disinfection of Bacteria. Because the retention time of wastewater in anaerobic lagoons can be as long as a few months, according to the information provided by the swine facility owner, the long-term effect of disinfection with FC was further examined in all wastewaters from systems A and B, over a time period of 7 days. Results in Figure $\mathbf{1 0}$ indicate that the bacteria population tends to rebound after an initial decrease in most cases, probably due to the availability of abundant organic materials and nutrients present in the wastewaters. However, a complete inactivation of bacteria is achieved with a $100 \mathrm{mg} / \mathrm{L}$ $\mathrm{FC}$ dose in $\mathrm{A}-\mathrm{OV}$ after 7 days and in $\mathrm{B}-\mathrm{OV}$ after 3 days. The OVs in both systems A and B have a lower initial bacteria population and less organic content than the INF and EFF, which may contribute to the higher disinfection efficiency obtained. With a $100 \mathrm{mg} / \mathrm{L} \mathrm{FC}$ dose, the concentration of total chlorine was determined in $\mathrm{B}-\mathrm{OV}$ to be $2.2 \mathrm{mg} / \mathrm{L}$ after 7 days. The persistence of total chlorine residue leads to continuous inactivation of bacteria in $\mathrm{B}-\mathrm{OV}$ and makes extended disinfection feasible.

Taking both antibiotics removal and bacterial inactivation into consideration, with a $100 \mathrm{mg} / \mathrm{L} \mathrm{FC} \mathrm{dose,} \mathrm{all} \mathrm{antibiotics} \mathrm{are}$ decomposed after $2.5 \mathrm{~h}$ and all bacteria are inactivated after 3 days in B-OV. In A-OV, although the bacteria are completely inactivated after 7 days at the same dose of FC, much more chlorine (i.e., $1100 \mathrm{mg} / \mathrm{L}$ ) is required to completely remove antibiotics because of its higher ammonia concentration. For the INF and EFF of both systems A and B, the FC dose for complete removal of antibiotics ranges from 700 to $2000 \mathrm{mg} /$ L. Ammonia plays a critical role in antibiotics decomposition. It is noted that intermittent aeration of lagoon B-1 significantly improved the performance of system $\mathrm{B}$, especially resulting in remarkable reduction of ammonia in B-EFF and B-OV. Therefore, a possible strategy for treatment of swine wastewater is to aerate the first-stage lagoon and chlorinate the EFF of the second-stage lagoon. The original anaerobic lagoons can remain unchanged, except for the installation of an aerator in the firststage lagoon to be used to aid in the degradation of organic materials and ammonia. An additional treatment tank can be appended to the second-stage lagoon for chlorination. The small flow rate of swine wastewater (and thus a small tank volume) and land availability generally on farms makes this construction possible. Although treatment of lagoon bottom sludge that antibiotics may partition to, and identification of chlorination byproducts, are beyond the scope of this study, they warrant further investigation.

This research has demonstrated that high chlorine doses are required to remove sulfonamide antibiotics from lagoon overflow prior to discharge into the environment even in the case of optimized treatment (i.e., an aerated first-stage lagoon followed by a second-stage polishing lagoon). Such high chlorine doses are likely to create high concentrations of chlorinated disinfection byproducts with potential environmental or human toxicity. These results suggest that the adoption in the United States of the European Union policy of not using antibiotics for growth promotion at CAFOs may be a better means of reducing the release of antibiotics and antibiotic resistant bacteria into the environment than treating the EFF waters.

\section{LITERATURE CITED}

(1) Gustafson, R. H.; Bowen, R. E. Antibiotic use in animal agriculture. J. Appl. Microbiol. 1997, 83, 531-541.

(2) Diarra, M. S.; Malouin, F.; Jacques, M. Postantibiotic and physiological effects of tilmicosin, tylosin, and apramycin at subminimal and suprainhibitory concentrations on some swine and bovine respiratory tract pathogens. Int. J. Antimicrob. Agents 1999, 12, 229-237.

(3) http://www.ucsusa.org/food_and_environment/antibiotics_and_food/european-union-ban.html (accessed on July 23, 2006).

(4) Levy, S. B. The challenge of antibiotic resistance. Sci. Am. 1998, 278 (3), 46-53.

(5) Meyer, M. T.; Bumgarner, J. E.; Varns, J. L.; Daughtridge, J. V.; Thurman, E. M.; Hostetler, K. A. Use of radioimmunoassay as a screen for antibiotics in confined animal feeding operations and confirmation by liquid chromatography/mass spectrometry. Sci. Total Environ. 2000, 248, 181-187.

(6) Teuber, M. Veterinary use and antibiotic resistance. Curr. Opin. Microbiol. 2001, 4, 493-499.

(7) Khachatourians, G. G. Agricultural use of antibiotics and the evolution and transfer of antibiotic-resistant bacteria. Can. Med. Assoc. J. 1998, 159, 1129-1136.

(8) Tolls, J. Sorption of veterinary pharmaceuticals in soils: A review. Environ. Sci. Technol. 2001, 35, 3397-3406.

(9) Addison, J. B. Antibiotics in sediments and run-off waters from feedlots. Residue Rev. 1984, 92, 1-28.

(10) Sweeten, J. M. Waste treatment: State-of-the-art. Livestock Waste: A Renewable Resource, Proceedings of the 4th International Symposium on Livestock Wastes; ASAE: St. Joseph, MI, 1980; pp 334-338.

(11) Cole, D.; Todd, L.; Wing, S. Concentrated swine feeding operations and public health: A review of occupational and community health effects. Environ. Health Perspect 2000, 108, 685-699.

(12) Barker, J. C.; Drigger, L. B. Pit recharge system for managing swine under floor manure pits. Agriculture Waste Utilization and Management, Proceedings of the 5th International Symposium on Agriculture Wastes; ASAE: St. Joseph, MI, 1985; pp 575581.

(13) Daughton, C. G.; Ternes, T. A. Pharmaceutical and personal care products in the environment: Agents of subtle change? Environ. Health Perspect. 1999, 107 (Suppl. 6), 907-938.

(14) Ingerslev, F.; Halling-Sorensen, B. Biodegradability properties of sulfonamides in activated sludge. Environ. Toxicol. Chem. 2000, 19, 2467-2473.

(15) Meyer, M.; Ferrell, G.; Bumgarner, J.; Cole, D.; Hutchins, S.; Krapac, I.; Johnson, K.; Verstraeten, I.; Kolpin, D. Occurrence of antibiotics in hog-waste lagoons from confined animal feeding operations from 1998-2002: indicators of antibiotic usage. Proceedings of the 3rd International Conference on Pharmaceuticals and Endocrine Disrupting Chemicals in Water, Minneapolis, MN, March 19-21, 2003.

(16) Kolpin, D. W.; Furlong, E. T.; Meyer, M. T.; Thurman, E. M.; Zaugg, S. D.; Barber, L. B.; Buxton, H. T. Pharmaceuticals, hormones, and other organic wastewater contaminants in U.S. streams, 1999-2000: A national reconnaissance. Environ. Sci. Technol. 2002, 36, 1202-1211. 
(17) Holm, J. V.; Rugge, K.; Bjerg, P. L.; Christensen, T. H. Occurrence and distribution of pharmaceutical organic compounds in the groundwater downgradient of a landfill (Grindsted, Denmark). Environ. Sci. Technol. 1995, 29, 1415-1420.

(18) Sacher, F.; Lange, F. T.; Brauch, H. J.; Blankenhorn, I. Pharmaceuticals in groundwaters analytical methods and results of a monitoring program in Baden-Wurttemberg, Germany. $J$. Chromatogr. A 2001, 938, 199-210.

(19) Campagnolo, E. R.; Johnson, K. R.; Karpati, A.; Rubin, C. S.; Kolpin, D. W.; Meyer, M. T.; Esteban, J. E.; Currier, R. W.; Smith, K.; Thu, K. M.; McGeehin, M. Antimicrobial residues in animal waste and water resources proximal to large-scale swine and poultry feeding operations. Sci. Total Environ. 2002, 299, 89-95.

(20) Hamscher, G.; Sczesny, S.; Hoper, H.; Nau, H. Determination of persistent tetracycline residues in soil fertilized with liquid manure by high-performance liquid chromatography with electrospray ionization tandem mass spectrometry. Anal. Chem. 2002, $74,1509-1518$.

(21) Chee-Sanford, J. C.; Aminov, R. I.; Krapac, I. J.; GarriguesJeanjean, N.; Mackie, R. I. Occurrence and diversity of tetracycline resistance genes in lagoon and groundwater underlying two swine production facilities. Appl. Environ. Microbiol. 2001, 67, 1494-1502.

(22) Hileman, B. Troubled waters: EPA, USGS try to quantify prevalence, risks of compounds from drugs, personal care products. Chem. Eng. News 2001, 79, 31-33.

(23) Witte, W. Medical consequences of antibiotic use in agriculture. Science 1998, 279 (5353), 996-997.

(24) van den Bogaard, A. E.; Stobberingh, E. E. Antibiotic usage in animals: Impact on bacterial resistance and public health. Drugs 1999, 58, 589-607.

(25) Goni-Urriza, M.; Capdepuy, M.; Arpin, C.; Raymond, N.; Caumette, P.; Quentin, C. Impact of an urban effluent on antibiotic resistance of riverine Enterobacteriaceae and Aeromonas spp. Appl. Environ. Microbiol. 2000, 66, 125-132.

(26) Krapac, I. G.; Dey, W. S.; Roy, W. R.; Jellerichs, B. G.; Smyth, C. Groundwater quality near livestock manure pits. Proceedings of the 8th International Symposium on Animal, Agricultural and Food Processing Wastes; American Society for Agricultural Engineering: Des Moines, IA, 2000; pp 710-718.

(27) Buser, H. R.; Poiger, T.; Müller, M. D. Occurrence and fate of the pharmaceutical drug diclofenac in surface waters: Rapid photodegradation in a lake. Environ. Sci. Technol. 1998, 32, $3449-3456$

(28) Adams, C.; Wang, Y.; Loftin, K.; Meyer, M. Removal of antibiotics from surface and distilled water in conventional water treatment processes. J. Environ. Eng.-ASCE 2002, 128, 253260.

(29) Ternes, T. A.; Meisenheimer, M.; McDowell, D.; Sacher, F.; Brauch, H. J.; Haist-Gulde, B.; Preuss, G.; Wilme U.; ZuleiSeibert, N. Removal of pharmaceuticals during drinking water treatment. Environ. Sci. Technol. 2002, 36, 3855-3863.
(30) Huber, M. M.; Canonica, S.; Park, G. Y.; von Gunten, U. Oxidation of pharmaceuticals during ozonation and advanced oxidation processes. Environ. Sci. Technol. 2003, 37, 10161024.

(31) Qiang, Z.; Adams, C.; Surampalli, R. Determination of ozonation rate constants for lincomycin and spectinomycin. Ozone-Sci. Eng. 2004, 26, 525-537.

(32) Dodd, M. C.; Huang, C. H. Transformation of the antibacterial agent sulfamethoxazole in reactions with chlorine: kinetics, mechanisms, and pathways. Environ. Sci. Technol. 2004, 38, 5607-5615.

(33) Qiang, Z.; Adams, C. Determination of monochloramine formation rate constants with stopped-flow spectrophotometry. Environ. Sci. Technol. 2004a, 38, 1435-1444.

(34) Macauley, J. J.; Qiang, Z.; Adams, C. D.; Surampalli, R.; Mormile, M. R. Disinfection of swine wastewater using chlorine, ultraviolet light and ozone. Water Res. 2006, 40, 2017-2026.

(35) Atlas, R. M.; Brown, A. E.; Dobra, K. W.; Miller, L. Experimental Microbiology-Fundamentals and Applications; Macmillan Publishing Co.: New York, 1984; pp 110-111.

(36) Do, Y. S.; Schmidt, T. M.; Zahn, J. A.; Boyd, E. S.; de la Mora, A.; DiSpirito, A. A. Role of Rhodobacter sp. strain PS9, a purple non-sulfur photosynthetic bacterium isolated from an anaerobic swine waste lagoon, in odor remediation. Appl. Environ. Microbiol. 2003, 69, 1710-1720.

(37) Pinkston, K. E.; Sedlak, D. L. Transformation of aromatic etherand amine-containing pharmaceuticals during chlorine disinfection. Environ. Sci. Technol. 2004, 38, 4019-4025.

(38) Morris, J. C. The acid ionization constant of $\mathrm{HOCl}$ from 5 to 35․ J. Phys. Chem. 1966, 70, 3798-3805.

(39) Qiang, Z.; Adams, C. Potentiometric determination of acid dissociation constants $\left(\mathrm{pK}_{\mathrm{a}}\right)$ for human and veterinary antibiotics. Water Res. 2004b, 38, 2874-2890.

(40) U.S. Environmental Protection Agency. Alternative Disinfectants and Oxidants Guidance Manual; U.S. EPA: Washington, DC, 1999; EPA-815-R-99-014.

(41) Gray, E. T., Jr.; Margerum, D. W.; Huffman, R. P. Chloramine equilibriums and the kinetics of disproportionation in aqueous solution. In Organometals and Organometalloids: Occurrence and Fate in the Environment; Brinckman, F. E., Bellama, J. M., Eds.; ACS Symposium Series 82; American Chemical Society: Washington, DC, 1978; pp 264-277.

Received for review March 20, 2006. Revised manuscript received August 11, 2006. Accepted August 14, 2006. We acknowledge the U.S. EPA for financial support on this project through Grant \#XP99795901-0 and the Environmental Research Center for Emerging Contaminants of UMR for additional instrumental support.

JF060779H 